\title{
Superposition of Four Generations of Folds and Development of Horse Creek Dome, Black Hills, South Dakota
}

\author{
Abdullah O. Bamousa* \\ Geology Department, Faculty of Science, Taibah University, P.O. Box 30002, Madinah, Saudi Arabia
}

\begin{abstract}
The study area is a part of the Precambrian basement of the Black Hills that was uplifted during Laramide Orogeny. Early Proterozoic meta-conglomerate and greywacke units occupy the study area and form a crescent fold which is unusual structural pattern, mapped in the Precambrian core of the Black Hills. This study aims to determine how the crescent shape was formed via fieldwork investigation and structural data analysis. Four Precambrian $\left(\mathrm{F}_{1}, \mathrm{~F}_{2}, \mathrm{~F}_{3}\right.$ and $\left.\mathrm{F}_{4}\right)$ folding events affected the study area prior to the uplift. Minor folds indicated that $F_{1}$ and $F_{4}$ exhibited isoclinal folding, $F_{2}$ reflected similar folding and $F_{3}$ displayed kink band and chevron folding. $F_{2}$ is associated with axial plane cleavage $\left(\mathrm{S}_{2}\right)$, trends towards the west, and is associated with regional metamorphism. $\mathrm{F}_{3}$ trends NNW and is associated with spaced cleavage $\left(\mathrm{S}_{3}\right) . \mathrm{F}_{4}$ trends WSW and is associated with spaced crenulation cleavage $\left(\mathrm{S}_{4}\right)$. The area was structurally divided into five domains. Poles to bedding $\left(\mathrm{S}_{0}\right)$ and axial plane cleavage $\left(\mathrm{S}_{2}\right)$ equal area stereographic projections show steeply plunging maxima that have monoclinic symmetry, resulting from superposition of two oblique $F_{2}$ and $F_{3}$ folding events. Domain I contains the Horse Creek dome that resulted from superposition of $F_{3}$ on $F_{2}$. The meta-conglomerate unit formed a crescent fold, due to superposition of the first two generations of folds. The crescent fold follows the Horse Creek dome, trends and opens westerly, and it is parallel to $\mathrm{F}_{4}$ folds.
\end{abstract}

Keywords: Horse Creek, Superposed Folds, Black Hills Precambrian Core, Early Proterozoic Rocks.

\section{INTRODUCTION}

During Early Proterozoic, the Precambrian core of the Black Hills uplift is believed to have been affected by northeasterly trending nappe folds $\left(\mathrm{F}_{1}\right)$ and north-northwest trending folds $\left(\mathrm{F}_{2}\right)$ associated with regional metamorphism preceding emplacement of the Harney Peak granite [1]. Along Horse Creek, about $30 \mathrm{~km}$ west of Rapid City, however, the outcrop pattern of the Precambrian rocks does not seem to support this deformational scheme because it displays a westerly trending crescent fold, which is a very unusual contact pattern and differs from any known structure in the Precambrian region of the Black Hills (Fig. 1).

An explanation of the crescent fold was the main objective of this study. Moreover, in this study an attempt was made to determine deformation events that may have produced the development of the crescent geometry. This study presents the fieldwork investigation, structural data collection and interpretation of Bamousa [2]. The study area is in the center of four adjoining (1:24000) quadrangles. The northern quads, Pactola Dam [3] and Silver City [4] were published by the South Dakota Geological Survey, but remapping of the southern Hill City and Mount Rushmore quads are in-press. The Hill City Quad was initially mapped by Ratté and Wayland [5].

\section{PRECAMBRIAN FRAMEWORK}

The Precambrian core of the Black Hills uplift varies in age from Late Archean to Early Proterozoic. The rock units

*Address correspondence to this author at the Geology Department, Faculty of Science, Taibah University, P.O. Box 30002, Madinah, Saudi Arabia; Tel: +96648460008, Ext. 1432; Fax: +96648454770;

E-mail: aobamousa@gmail.com in the study area are part of the Early Proterozoic units that comprise more than $90 \%$ of the Precambrian exposures, about $75 \%$ of the Precambrian core, and are dominated by $(\approx$ $1.97-1.88 \mathrm{Ga}$ ) deep-water turbidites [1]. The turbidites are deep-water deposits characterized by proximal to medial turbiditic greywacke, metamorphosed to quartzite and phyllite, and contain garnet in the more distal material [6]. The turbidites grade from a thick quartz-rich Buma A upward to a thinner, mica-rich Buma D and $\mathrm{E}$, in which sedimentary features may be well preserved [7].

The nappe $\left(\mathrm{F}_{1}\right)$ folds resulted from ca. 1,780 Ma islandarc accretion to the south [8]. The $\left(\mathrm{F}_{2}\right)$ folds formed during east-west collision of the Wyoming and Superior provinces, in which this collision began at or before ca. 1,770 Ma and culminated with post-tectonic magmatism (the Harney Peak granite) beginning ca 1,715 Ma [8]. The emplacement of the Harney Peak granite formed major and minor domes, which deform and warp the structural features into parallelism with the granite [1]. Also, it is suggested that the generation of Harney Peak granite during the Proterozoic Trans-Hudson Orogeny is best explained by shear heating during thrusting of a Proterozoic sedimentary sequence over the Archean Wyoming basement [9].

Early Proterozoic rocks underwent regional metamorphism that was followed by Abukuma-type thermal metamorphism due to emplacement of the Harney Peak Granite (HPG), which fits the classic chemical and lithological characteristics of an S-type granite [10]. The regional metamorphism began during crustal thickening [11]. The thermal metamorphism was probably transferred to the country rock by fluid evolved from the pegmatitic activity of HPG [12]. Friberg et al. [13] suggested two generations of garnet. Early garnets were formed during low 

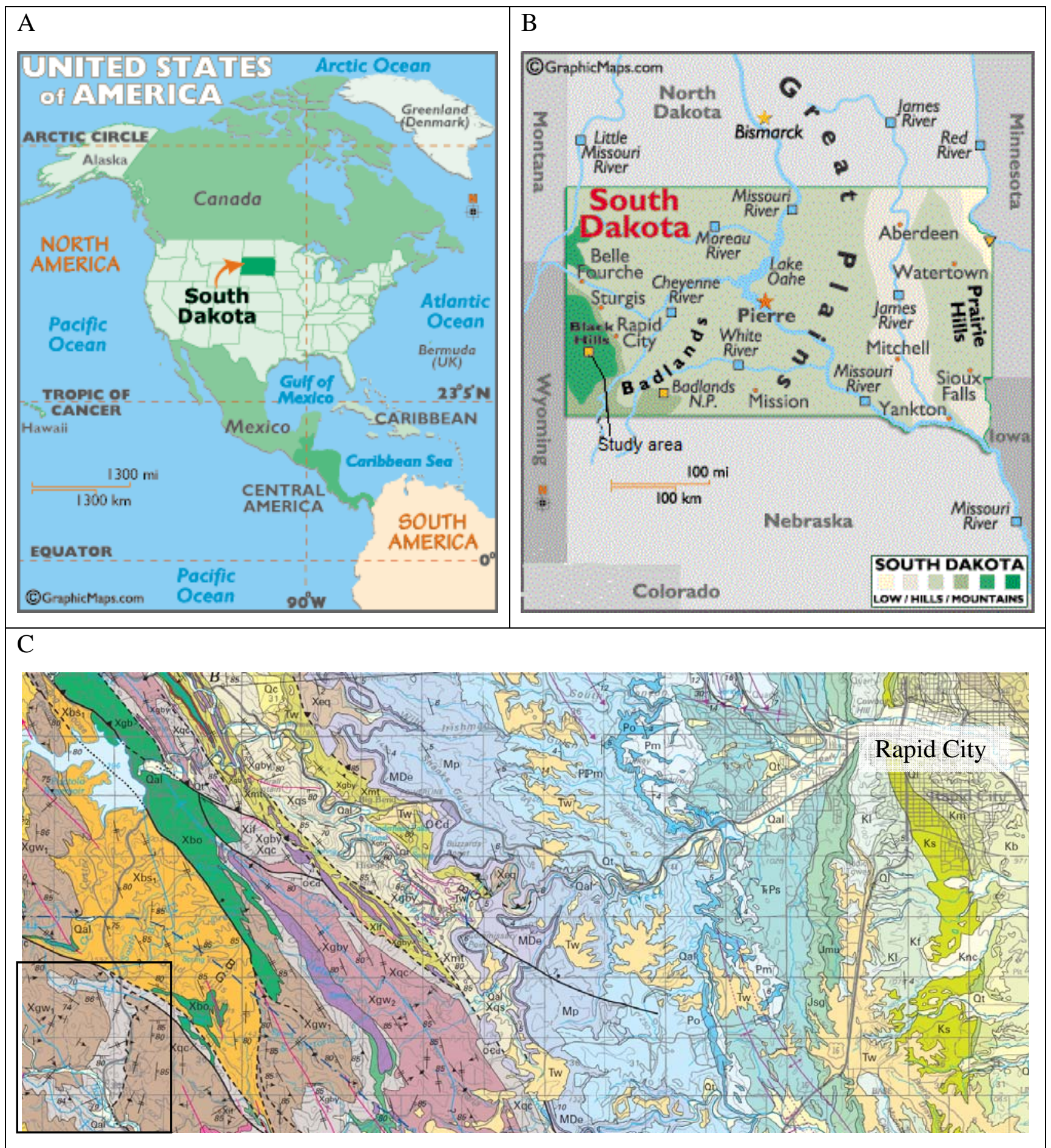

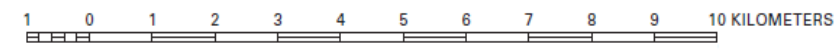

Fig. (1). A- Showing location of South Dakota (SD) State. B- Showing location of the study area within the Black Hills, SD. C- Geologic map of the study within the Precambrian core of Black Hills, small black square, $30 \mathrm{~km}$ southwest of Rapid City; adopted from Redden and DeWitt [17].

to medium-T regional metamorphism $\left(\leq 500^{\circ} \mathrm{C}\right)$ and were overprinted in most rocks by younger garnet growth, during medium to high-T $\left(\leq 660^{\circ}\right.$ C $)$ and low-P thermal metamorphism. Pressure along the northern contact of the HPG is estimated about 2.5-4.0 Kbar [7]. Intensity of metamorphism increases toward HPG.

\section{GEOLOGICAL SETTING OF THE STUDY AREA}

The rock units of the study area are exposed near Horse Creek, in the eastern core of the Black Hills, and north of Harney Peak granite. They include: Early Proterozoic (2.17 $1.98 \mathrm{Ga})$ meta-basalt $(\mathrm{Xb})$ and meta-shale (Xs); and Early 


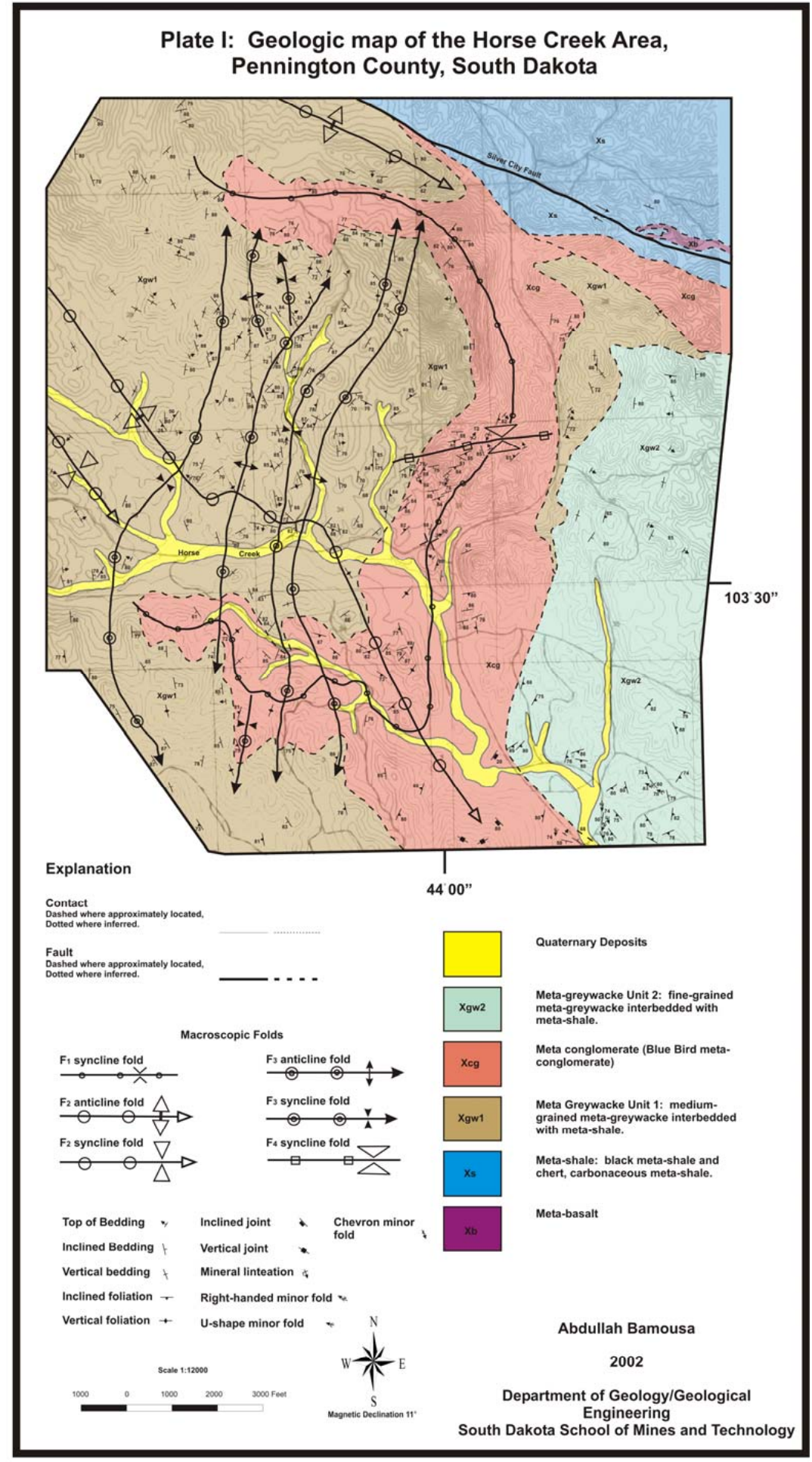

Fig. (2). Detailed geologic map of the study area.

Proterozoic $(\approx 1.97-1.88 \mathrm{Ga})$ deep-water turbidites as metagreywacke units $\left(\mathrm{Xgw}_{1}\right.$ and $\left.\mathrm{Xgw}_{2}\right)$ and the metaconglomerate (Xcg). The Xcg unit is believed to have been deposited in part as well-developed debris flows [14]. The meta-shale (Xs) unit occurs in the northeast portion of the study area. The meta-shale is a black, schistose, fine-grained rock. It consists largely of organic black shale and chert, carbonaceous shale, and a minor amount of siltstone metamorphosed into siliceous biotite phyllite and schist, and surrounds a pillowed greenstone meta-basalt $(\mathrm{Xb})$. The metashale is believed to have a thickness of greater than 782 meters [15]. The meta-shale bounds the meta-greywackes in the north along Silver City fault which trends westerly (Fig. 2). Previous workers believed that this fault is vertical, with dextral and normal components of movement [15]. 
The meta-greywacke unit $\mathrm{I}\left(\mathrm{Xgw}_{1}\right)$ underlies the area north and south of Horse Creek, and is composed of iron stained light-gray to dark-gray meta-greywacke on a freshly broken surface. Resistant quartzose beds form prominent outcrops interbedded with meta-shale in beds ranging from a foot to 6.1 meters thick. Under the hand lens, the grain size is fine to medium-grained sand, in which quartz (40\%) is the major constituent mineral, followed by feldspar (about 20 $\%$, and rock fragments; accessory minerals such as hematite, magnetite, and fine-grained dark matrix make up the rest of the composition. The meta-greywacke preserves depositional structures, such as channeling, graded bedding and lamination (Fig. 3). Graded beds are also present in the southwestern part of the study area, where the clasts are elongated collinearly with the general trend of the foliation. Also, meta-calc-silicate lenses that have been inferred as metamorphosed concretions are present. The $\mathrm{Xgw}_{1}$ unit resembles more proximal Buma sequence material than the meta-greywacke unit II $\left(\mathrm{Xgw}_{2}\right)$. Stratigraphic tops show that the $\mathrm{Xgw}_{1}$ contain the older turbidites in the study area.

The meta-conglomerate (Xcg) is present and obvious in the northern part of the study area, but it is very hard to recognize in the south. The grain size varies from pebbles to cobbles (Fig. 4), and the beds are 0.3 - 2 meters in thickness. However, more than $90 \%$ of the unit is bluish gray massive, fine-grained and thick beds ( $1-3$ meters) of quartzite that form the large crescent fold seen on Fig. (2). The quartzite beds grade into greenish-brown phyllite with chevron and Ushape minor folds in the middle of the study area. Meta-chert beds are interbedded with the Xcg in the south of the study area. Ratté and Wayland [5] found breccia in the Hill City

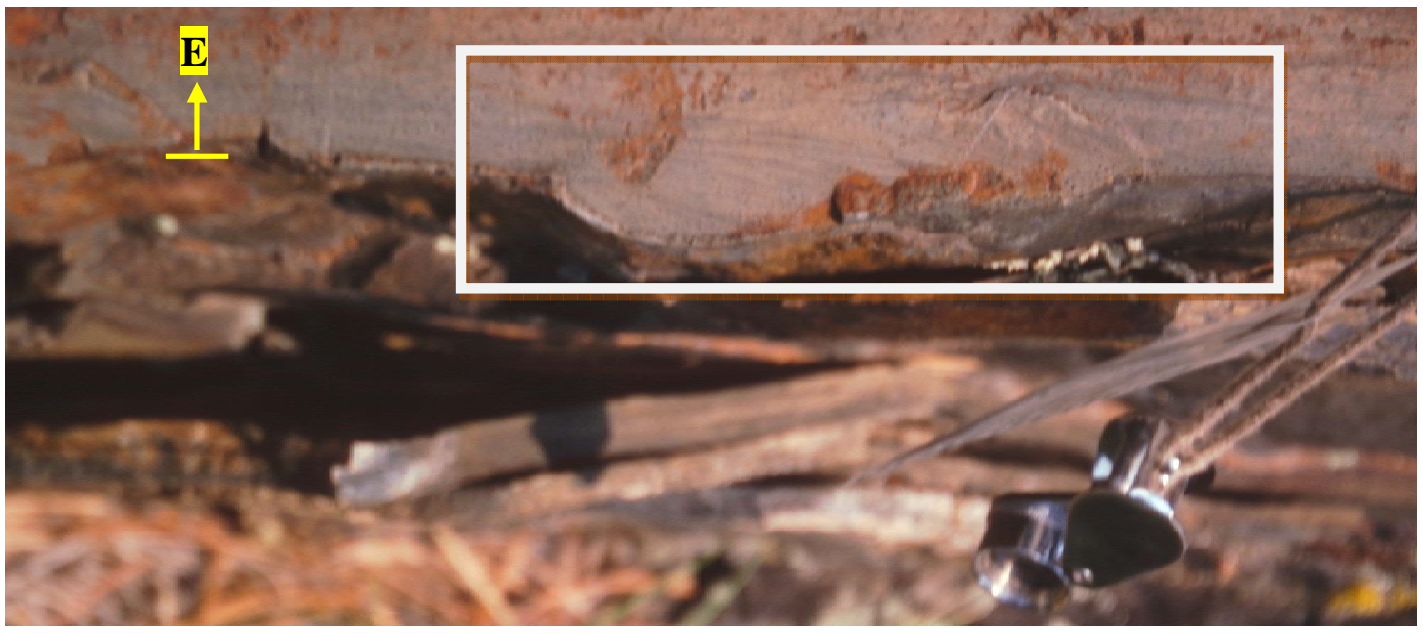

Fig. (3). Lamination and channeling on the lower contact of a subvertical bed of the $\mathrm{Xgw}_{1}$, unit, inside the rectangle. The arrow shows top direction towards the east.

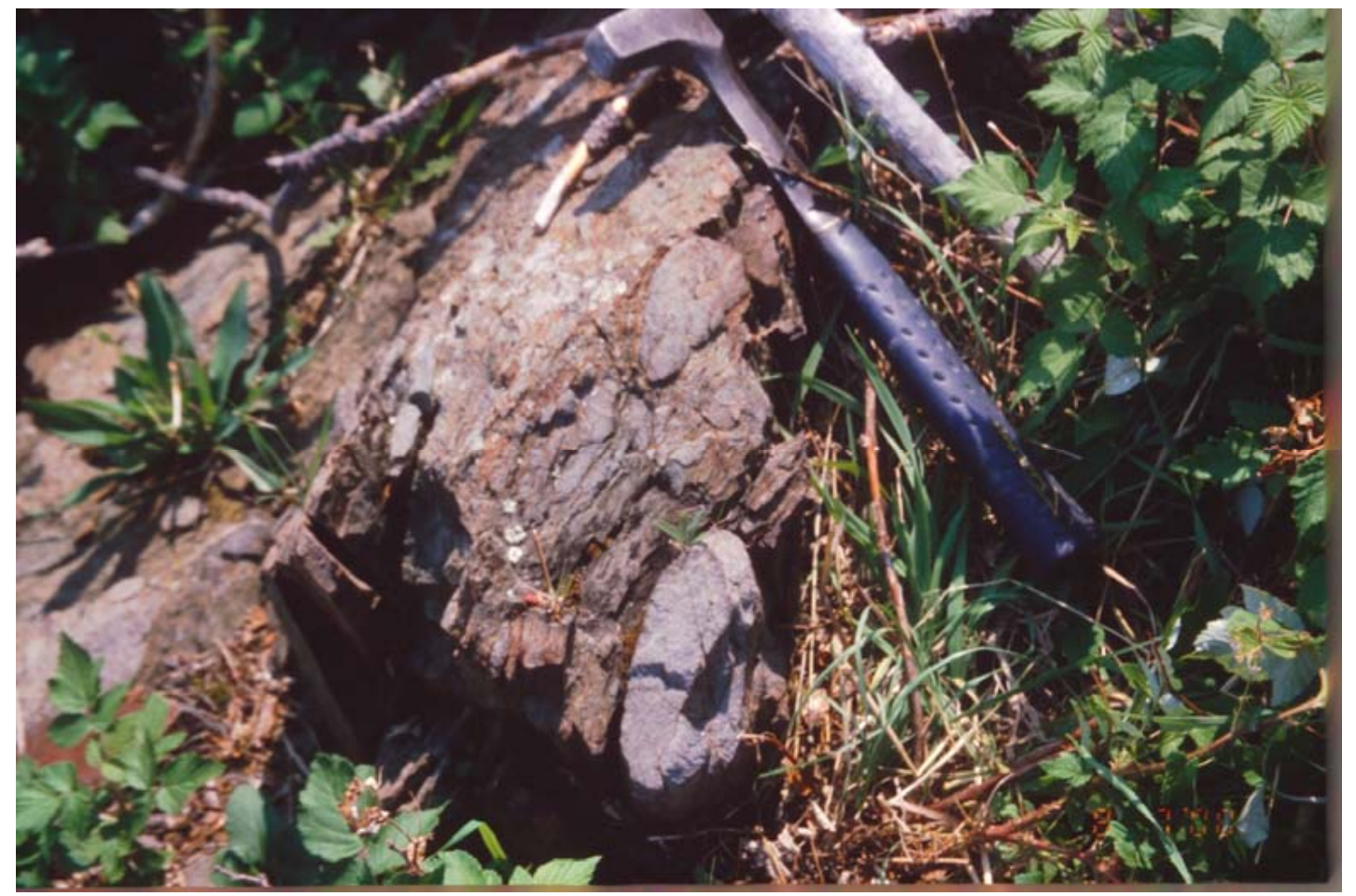

Fig. (4). Pebble and cobble sized clasts, encountered near the northern contact of the Xcg unit. 
Quadrangle, which might be equivalent to the metaconglomerate. The Sheridan Lake fault is inferred to bound the crescent fold on the east (Fig. 2). This fault might represent a tectono-depositional break because the Xcg splits the $\mathrm{Xgw}_{1}$ unit; thus, the fault might be younger than $\mathrm{F}_{1}$. The fault was probably reactivated as a reverse fault during $\mathrm{F}_{2}$ folds, separating Xcg from Xgw units.

The meta-greywacke unit II $\left(\mathrm{Xgw}_{2}\right)$ underlies the area to the east, and is composed dominantly of greywacke that is light to yellowish gray on a fresh break. It contains a large amount of biotite and a minor garnet component. It also shows layers that contain original interbedding of sandstone and shale. Thickness of beds varies from a few centimeters to 2 or 3 meters. The greywacke of this unit is very similar in composition to the more proximal greywacke of $\mathrm{Xgw}_{1}$, but the grain size of the Buma A beds are generally fine-grained. In the southeastern part of the study area, there is a bed of coarse-grained sands, about 10 meters thick associated with reddish quartz veins.

\section{SUPERPOSED FOLDING}

\section{Early Folds $\left(F_{1}\right)$}

$\mathrm{F}_{1}$ nappe folds are completely overprinted by younger folds, but the outcrop pattern of the meta-conglomerate (Xcg) shows early folds of $F_{1}$. The axial surface of $F_{1}$ is parallel to the two contacts of the Xcg, and is believed to be a syncline that was subsequently folded by $F_{2}$ : it forms the crescent fold (Fig. 2). This crescent fold of the $F_{1}$ axial surface opens to the west and comprises an area of about 4.8 $\mathrm{km}^{2}$. Fig. (5) shows a possible refolded isoclinal $F_{1}$ fold deformed by faults associated with the hinge area.

\section{Second Generation Folds $\left(\mathbf{F}_{2}\right)$}

The axial plane of $F_{2}$ trends northwesterly, superposed across the axial plane of $\mathrm{F}_{1}$, and approximately bisects the crescent fold (Fig. 2). There are three major $F_{2}$ folds in the study area as shown by the distribution of tops (Fig. 2). The major $\mathrm{F}_{2}$ folds vary in amplitude from 0.64 to $2.9 \mathrm{~km}$, plunge to the southeast and extend far to the west (Fig. 2). Better understanding of the $F_{2}$ nature is found in several outcropscale designated $F_{2}$ folds, which reflect similar folds that have associated axial plane cleavages $\left(\mathrm{S}_{2} ;\right.$ Figs. 6, 7).

\section{Third Generation Folds $\left(\mathbf{F}_{\mathbf{3}}\right)$}

The doubly plunging major axes of $\mathrm{F}_{3}$ trend northnortheasterly, occupy the area along Horse Creek, and crosscut the noses of the Xcg (Fig. 2). $\mathrm{F}_{3}$ axial traces are about $3.2 \mathrm{~km}$ long and vary in amplitude from 0.16 to 0.32 $\mathrm{km} . \mathrm{F}_{3}$ folded $\mathrm{F}_{2}$ and formed the Horse Creek dome (Fig. 2). The Horse Creek dome has an area of about a $1.6 \mathrm{~km}$ width by about $3.2 \mathrm{~km}$ long. A mesoscopic well-exposed steeply inclined and asymmetrical anticline near Horse Creek is designated $\mathrm{F}_{3}$ (Fig. 8). This $\mathrm{F}_{3}$ fold is called Horse Creek fold, and is associated with spaced cleavages $\left(\mathrm{S}_{3}\right)$. The Horse Creek fold has a length to amplitude ratio of $1: 3$. West of the Horse Creek $\mathrm{F}_{3}$ fold, the bedding attitude changes from north to west, which may indicate a return to the secondgeneration fold $\mathrm{F}_{2}$ trend. Many minor, nearly vertically plunging folds designated $\mathrm{F}_{3}$ deform $\mathrm{S}_{2}$ and refold $\mathrm{S}_{0}$. These folds are asymmetric $S$-type and chevron minor folds (Figs. 9-11), reflecting that $F_{3}$ is related to late shearing event.fold, and is associated with spaced cleavages $\left(\mathrm{S}_{3}\right)$. The Horse

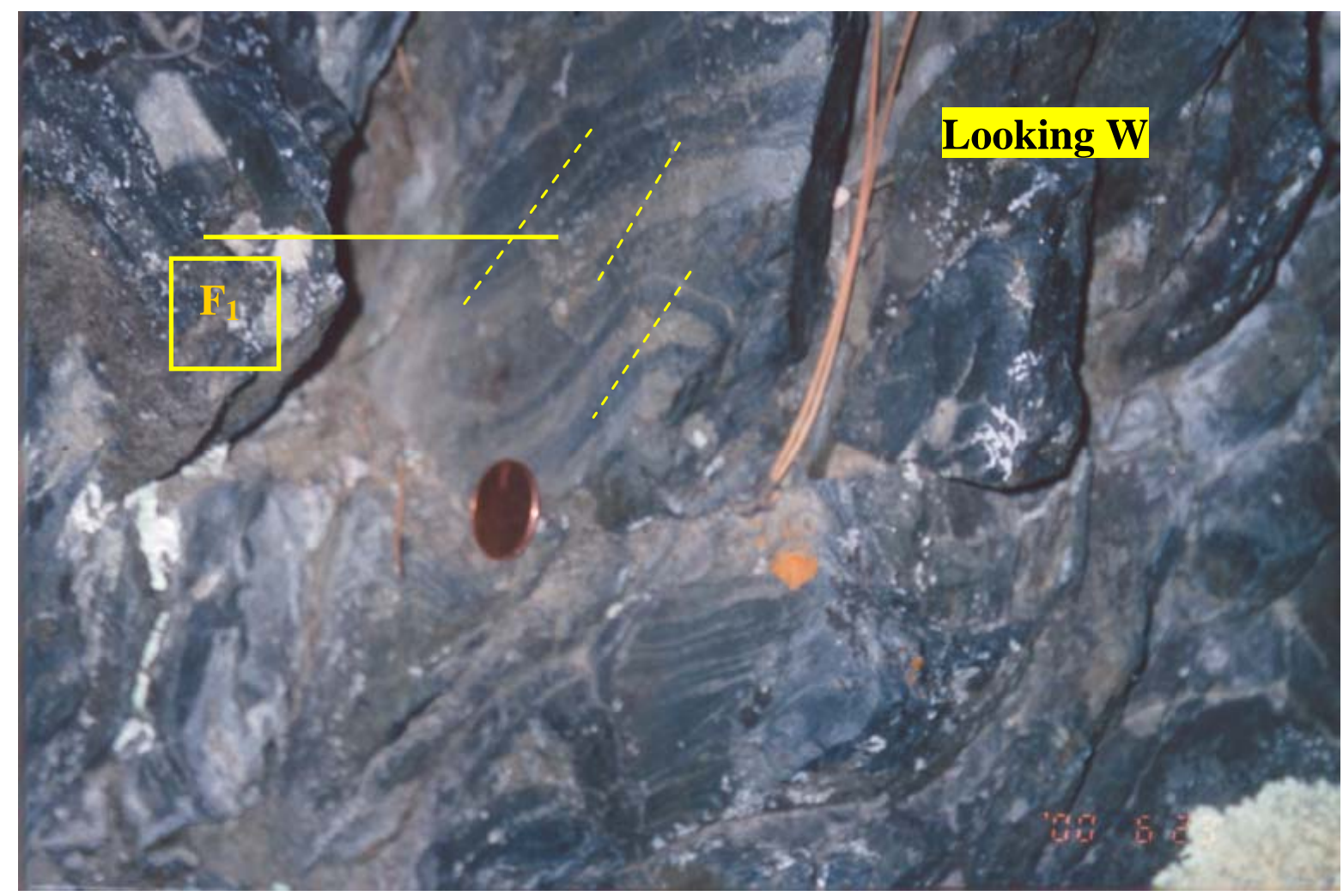

Fig. (5). Photograph showing possible isoclinal fold $\left(\mathrm{F}_{1}\right)$ that had been refolded and faulted (dashed lines). This picture is an exposure of a fracture surface. 


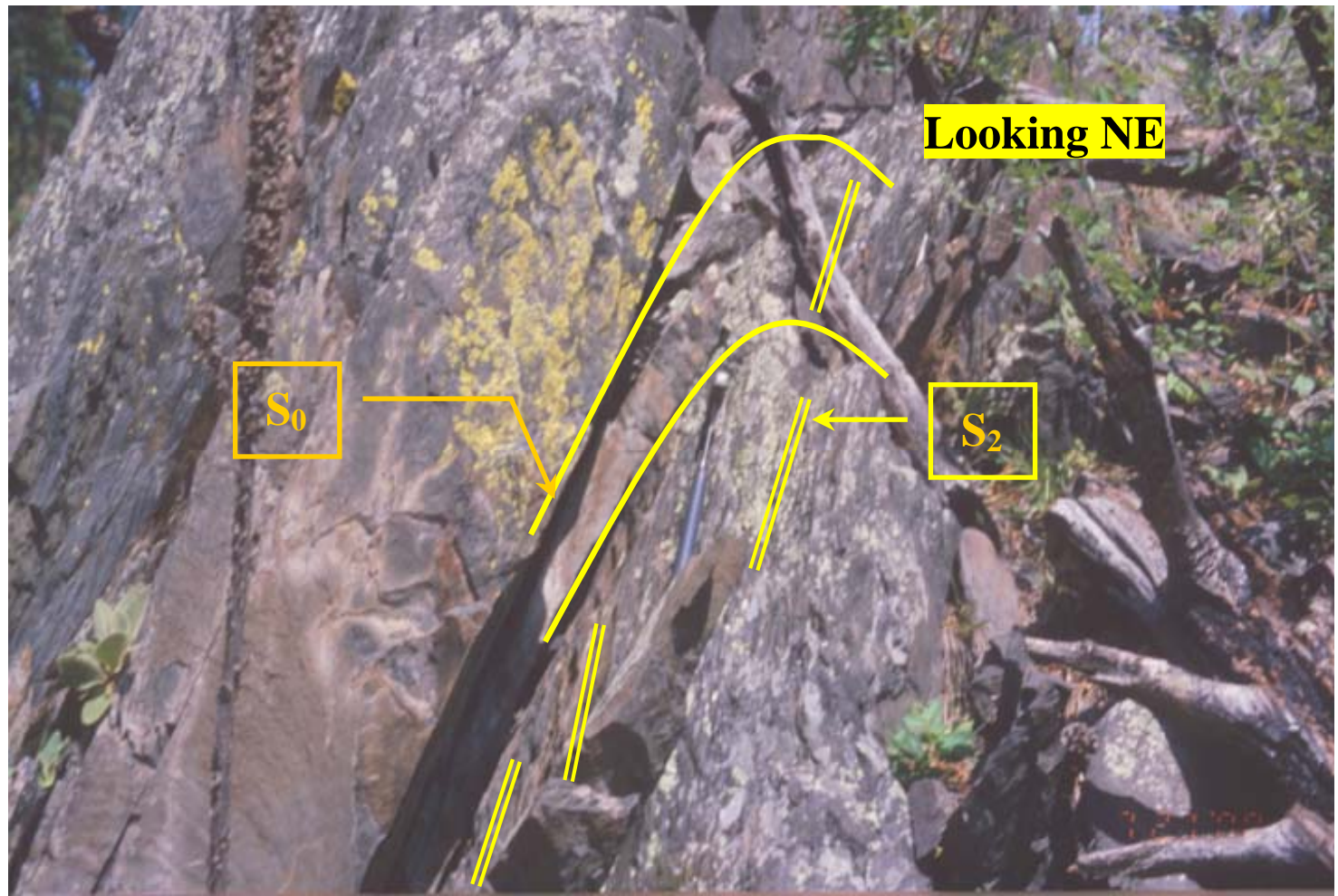

Fig. (6). Similar folding $\left(\mathrm{F}_{2}\right)$, with one limb removed by weathering. The picture reflects that $\mathrm{F}_{2}$ is associated with $\mathrm{S}_{2}$ axial plane cleavage.

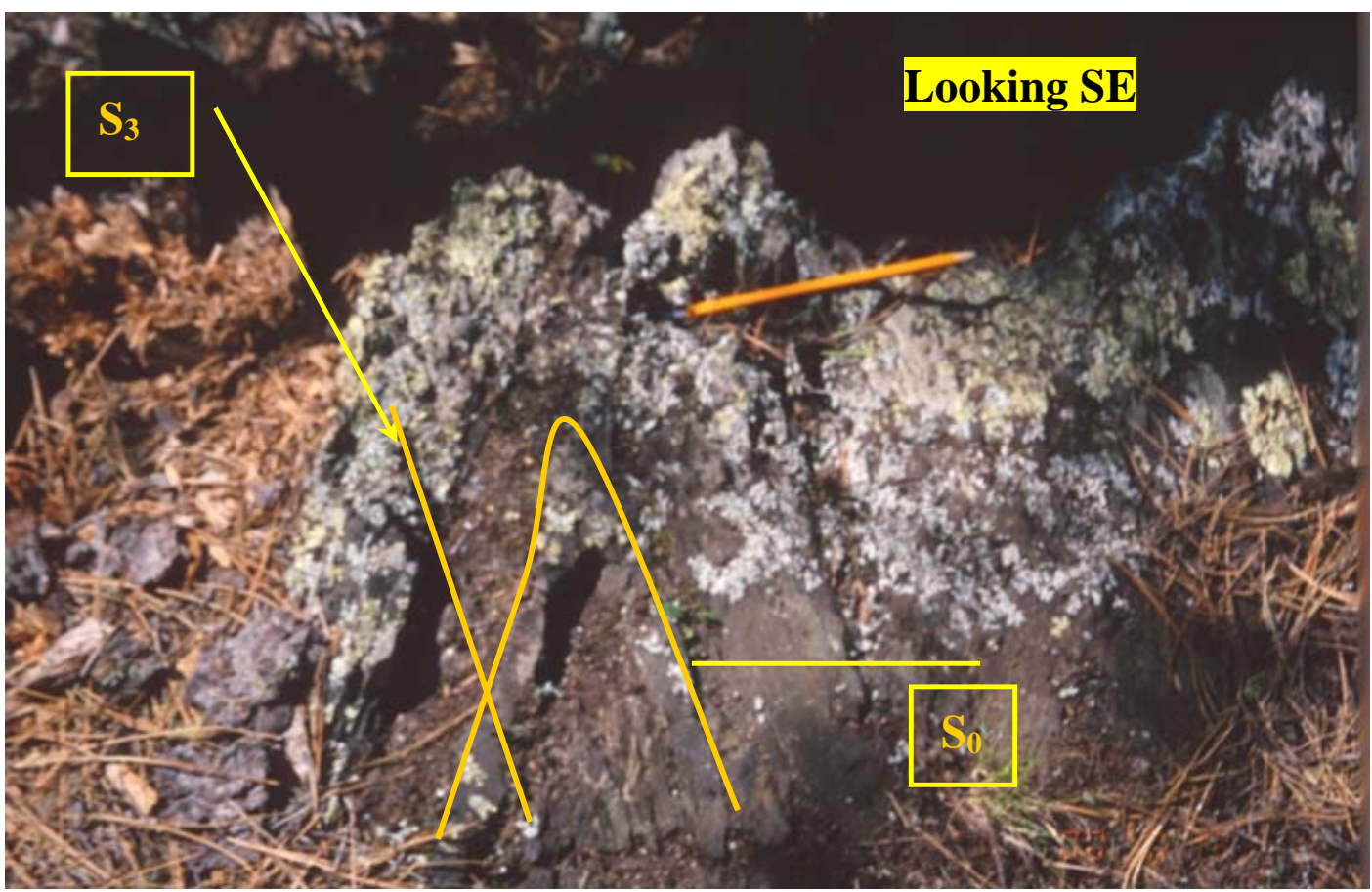

Fig. (7). A meta-calc-silicate bed forming a similar $F_{2}$ fold, and cut by younger $S_{3}$ cleavage. The intersection of $S_{0}$ and $S_{3}$ formed boudinage structure.

Creek fold has a length to amplitude ratio of $1: 3$. West of the Horse Creek $\mathrm{F}_{3}$ fold, the bedding attitude changes from north to west, which may indicate a return to the secondgeneration fold $\mathrm{F}_{2}$ trend. Many minor, nearly vertically plunging folds designated $\mathrm{F}_{3}$ deform $\mathrm{S}_{2}$ and refold $\mathrm{S}_{0}$. These folds are asymmetric S-type and chevron minor folds (Figs. 9-11), reflecting that $F_{3}$ is related to late shearing event.

\section{Fourth Generation Folds $\left(\mathrm{F}_{4}\right)$}

The structural form lines of $\mathrm{S}_{0}$ within the metaconglomerate suggest that the study area is deformed by a fourth generation folding event, in which $\mathrm{F}_{3}$ is seemingly folded (Fig. 2). The axial trace of $F_{4}$ is about $1.45 \mathrm{~km}$ long. Westerly trending isoclinal, upright, and nearly horizontally plunging anticlines seen in two outcrops are designated $\mathrm{F}_{4}$ 


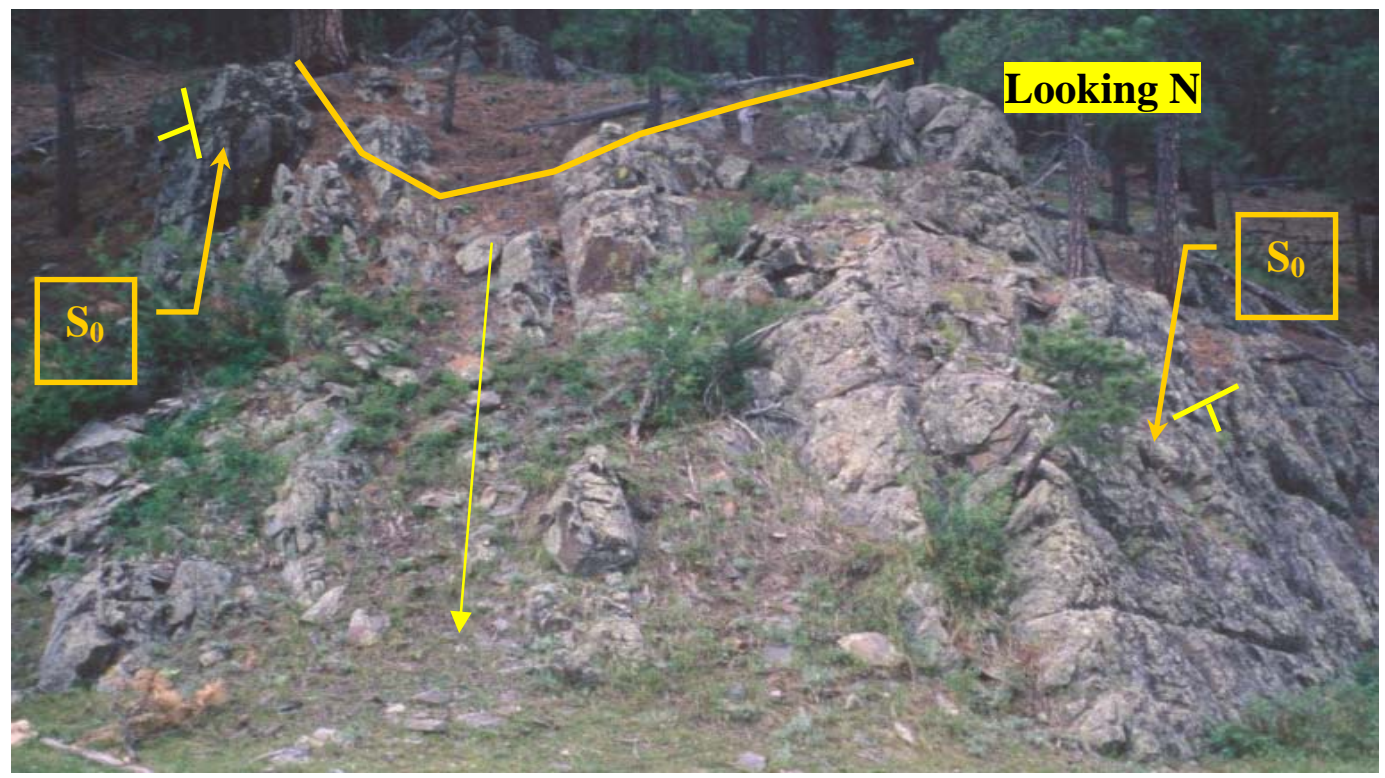

Fig. (8). Mesoscopic $F_{3}$ fold at Horse Creek trending northerly. Beds starting to trend westerly in the upper left part of the Fig.. This is a tight, asymmetrical, and steeply plunging fold.

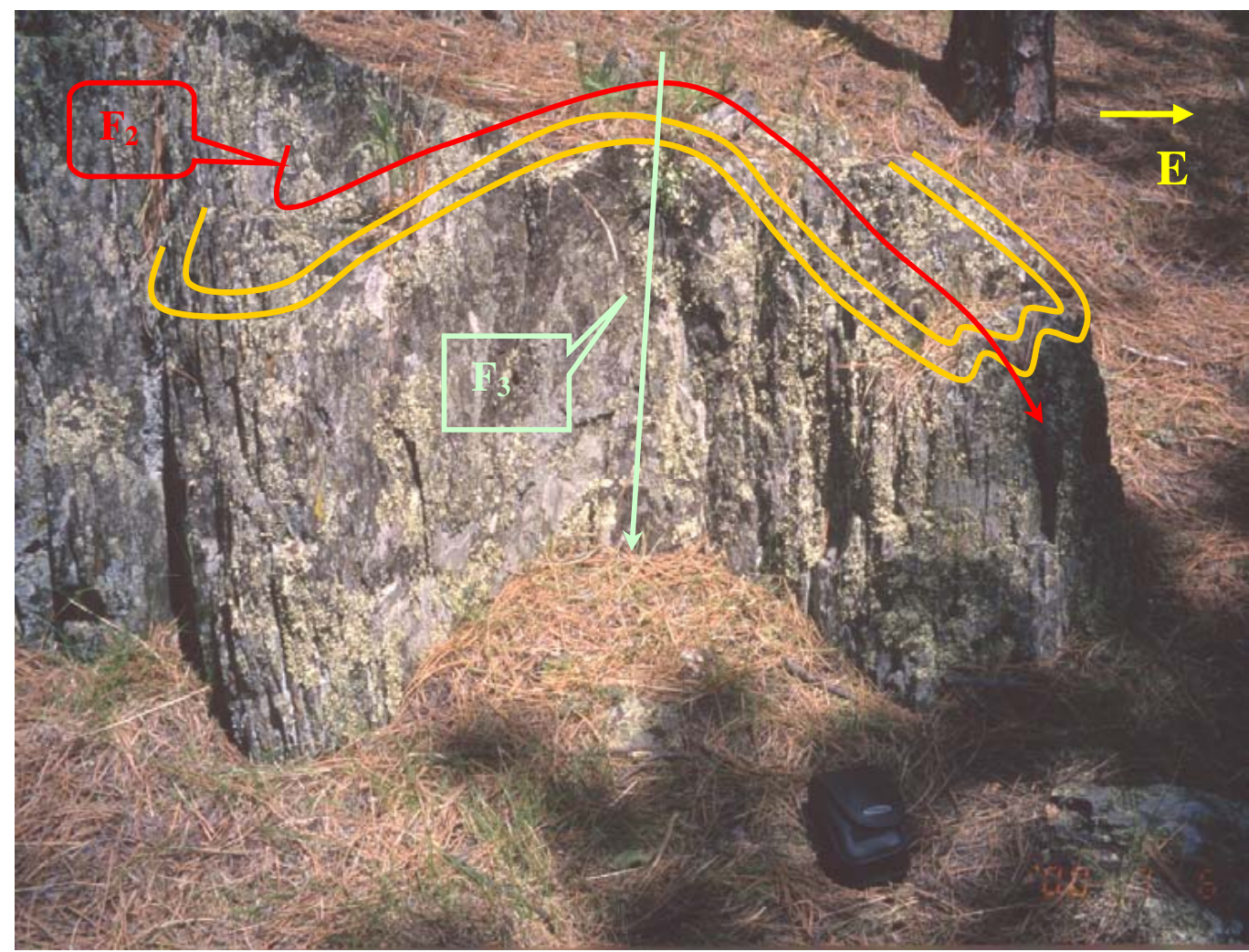

Fig. (9). Refolded $F_{2}$ fold in phyllite rock, reflecting a S-type fold. $F_{3}$ fold is associated with spaced cleavage $S_{3}$.

(Fig. 12). These two folds have amplitudes of 12 - 18 meters, and a wavelength of 3 meters; therefore, the ratio of the two is equal to 1:5. This type of fold has an isoclinal geometry and associated with closely spaced $\left(\mathrm{S}_{4}\right)$ crenulation cleavages. Incipient cleavages, interpreted as S4 crenulation cleavage, are present in the study area and are oblique to bedding (Fig. 13). Wavra [16] noticed in the Berne (7.5 Minuets) Quadrangle that crenulations formed during doming activity. Therefore, this surface might be related to emplacement of the Harney Peak granite. Moreover, the emplacement and doming of the Harney Peak granite reoriented the structure into parallelism with the northern circumference of Harney Peak.

\section{STRUCTURAL ANALYSIS}

The study area was subdivided into five domains, wherein each domain reflects different categories of superposition. This analysis shows only $\mathrm{S}_{0}$ and $\mathrm{S}_{2}$ relationships and interpretations because they are the most abundant surfaces in the study area (Fig. 14). 


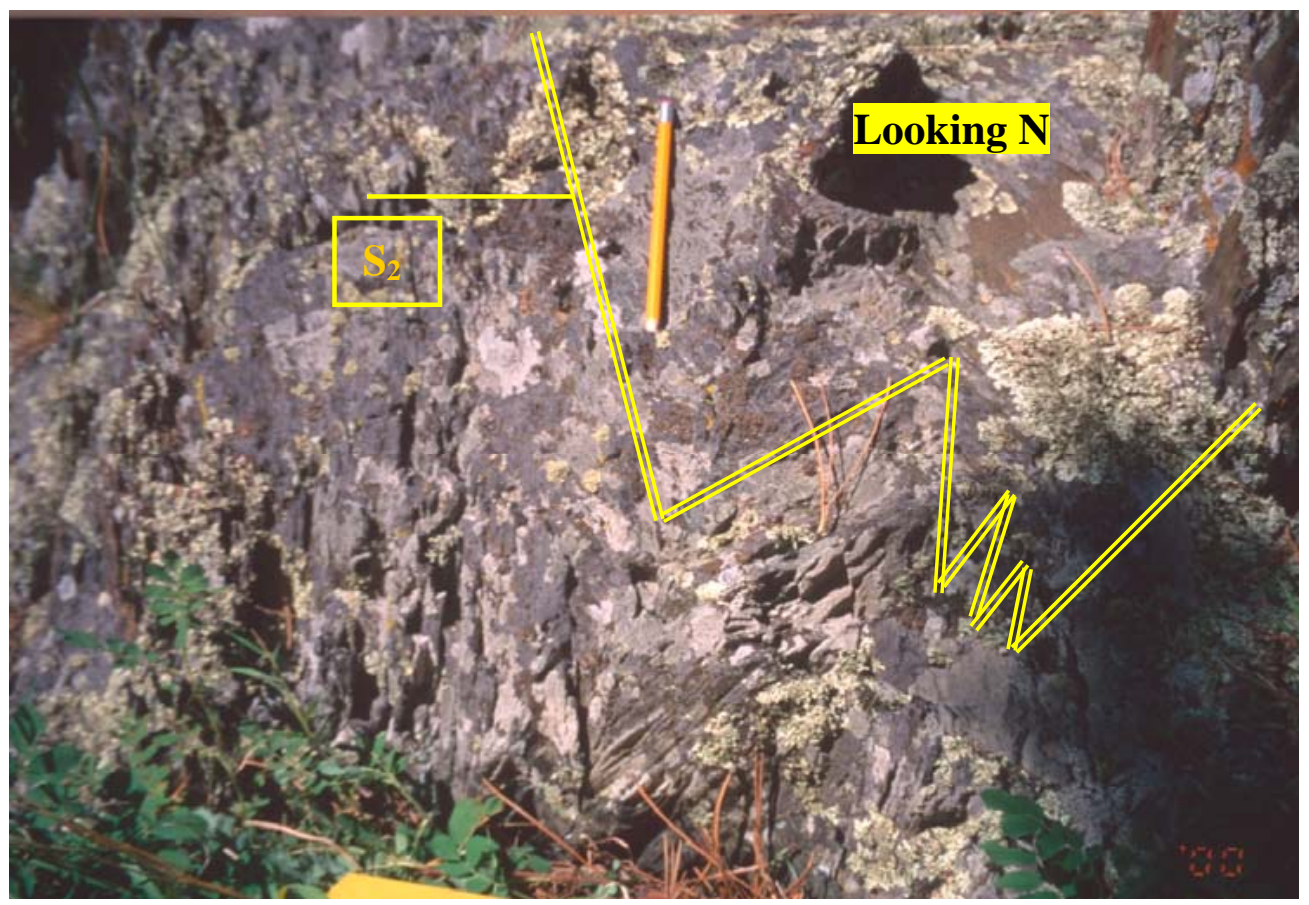

Fig. (10). Chevron folds deforming $S_{2}$ are abundant in phyllite along the western contact of the Xcg north of Horse Creek. The axial plane of this fold is parallel to the general northeasterly trend of $\mathrm{F}_{3}$.

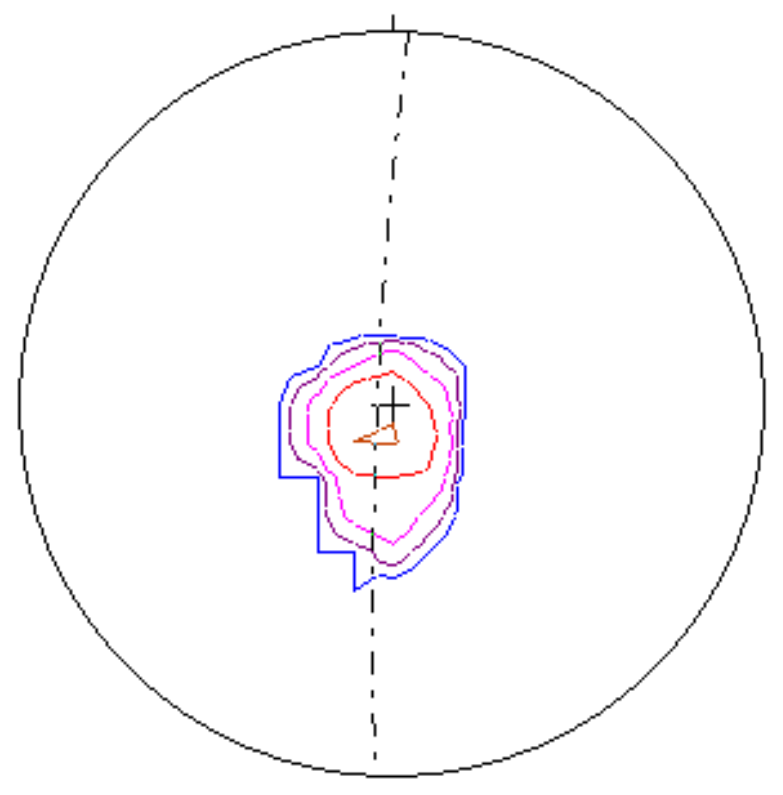

Fig. (11). Contours of plunges of $\mathrm{F}_{3}$ minor folds; $\mathrm{n}=25$, contours $4 \%, 8 \%, 16 \%, 32 \%$, and $64 \%$. Maximum plunge and trend $=83^{\circ}$, $\mathrm{S} 11^{\circ} \mathrm{W}$.

\section{Domain I}

Domain I occupies the core of the study area and is surrounded by the other domains. Only $\mathrm{Xgw}_{1}$ is exposed in this domain. This domain includes the Horse Creek dome that formed by superposition of $\mathrm{F}_{3}$ on $\mathrm{F}_{2}$ (Fig. 15). Fig. (14a) shows poles to bedding $\mathrm{S}_{0}$ that produce four asymmetric maxima $\left(7^{\circ}, 74^{\circ} \mathrm{E} ; 2^{\circ}, \mathrm{N} 53^{\circ} \mathrm{W} ; 2^{\circ}, \mathrm{S} 53^{\circ} \mathrm{W}\right.$; and $\left.10^{\circ}, \mathrm{N} 02^{\circ} \mathrm{E}\right)$ and define monoclinic symmetry. This distribution of poles to $S_{0}$ suggests equal development of two major limbs of tight, inclined, steeply plunging folds with right-handed or S- type folds and left-handed or Z-type minor folds. Poles to $\mathrm{S}_{2}$ cleavage plotted on an equal area net stereonet produce three monoclinic maxima $\left(5^{\circ}, \mathrm{S} 49^{\circ} \mathrm{E}, 5^{\circ}, \mathrm{S} 75^{\circ} \mathrm{E}\right.$, and $\left.12^{\circ}, \mathrm{N} 34^{\circ} \mathrm{E}\right)$ (Fig. 14a). This distribution suggests two equally developed major limbs of very tight, nearly vertical plunging, isoclinal fold with S-type minor folds. The angle between the two limbs, however, seems to be tighter than $\mathrm{S}_{0}$ poles.

\section{Domain II}

This domain is situated east of Domain I and is bounded by a fault on the north. The $\mathrm{Xcg}, \mathrm{Xgw}_{1}$ and $\mathrm{Xgw}_{2}$ units are exposed. It includes $F_{1}, F_{2}, F_{3}$ folds (Fig. 15), and a strong westerly trending pattern suggests that $F_{4}$ is also present and superposed the crescent fold (Fig. 15). Poles to bedding $\left(S_{0}\right)$ produce two major maxima $\left(8^{\circ}, \mathrm{N} 77^{\circ} \mathrm{W}\right.$ and $\left.4^{\circ}, \mathrm{N} 1^{\circ} \mathrm{E}\right)$ with a monoclinic pattern (Fig. 14b). This distribution suggests two major limbs of open, inclined, and steeply plunging folds with development of S-type minor folds. Poles to $\mathrm{S}_{2}$ produce six maxima $\left(7^{\circ}, \mathrm{N} 83^{\circ} \mathrm{W}, 8^{\circ}, \mathrm{N} 55^{\circ} \mathrm{W}, 8^{\circ}, \mathrm{N} 28^{\circ} \mathrm{W}, 12, \mathrm{~N} 8^{\circ} \mathrm{E}\right.$, 20, $\mathrm{N} 39^{\circ} \mathrm{E}$, and $6^{\circ}, \mathrm{N} 71^{\circ} \mathrm{E}$ ) suggesting nearly vertical isoclinal folding with development of S-type minor folds (Fig. 13b).

\section{Domain III}

This domain is situated north of Domain I and bounded by a fault on the east. The northern nose of the $F_{1}$ fold containing $\mathrm{Xcg}$ and the surrounding material of $\mathrm{Xgw}_{1}$ is exposed. This domain has $\mathrm{F}_{3}$ and $\mathrm{F}_{1}$ folds superimposed (Fig. 15). $F_{2}$ is also present and trends west (Fig. 15). Poles to bedding $\left(\mathrm{S}_{0}\right)$ in this domain produce one major maxima $\left(11^{\circ}\right.$, $\left.\mathrm{N} 88^{\circ} \mathrm{W}\right)$ and one sub-maxima $\left(11^{\circ}, \mathrm{N} 48^{\circ} \mathrm{W}\right)$ that form a monoclinic pattern, very similar to that found in Domain $\mathrm{V}$ (Fig. 14c). This domain may also be a mirror image of Domain V (Fig. 14e). Both domains are characterized by superposition of $F_{3}$ and $F_{1}$, in which the distribution of the 


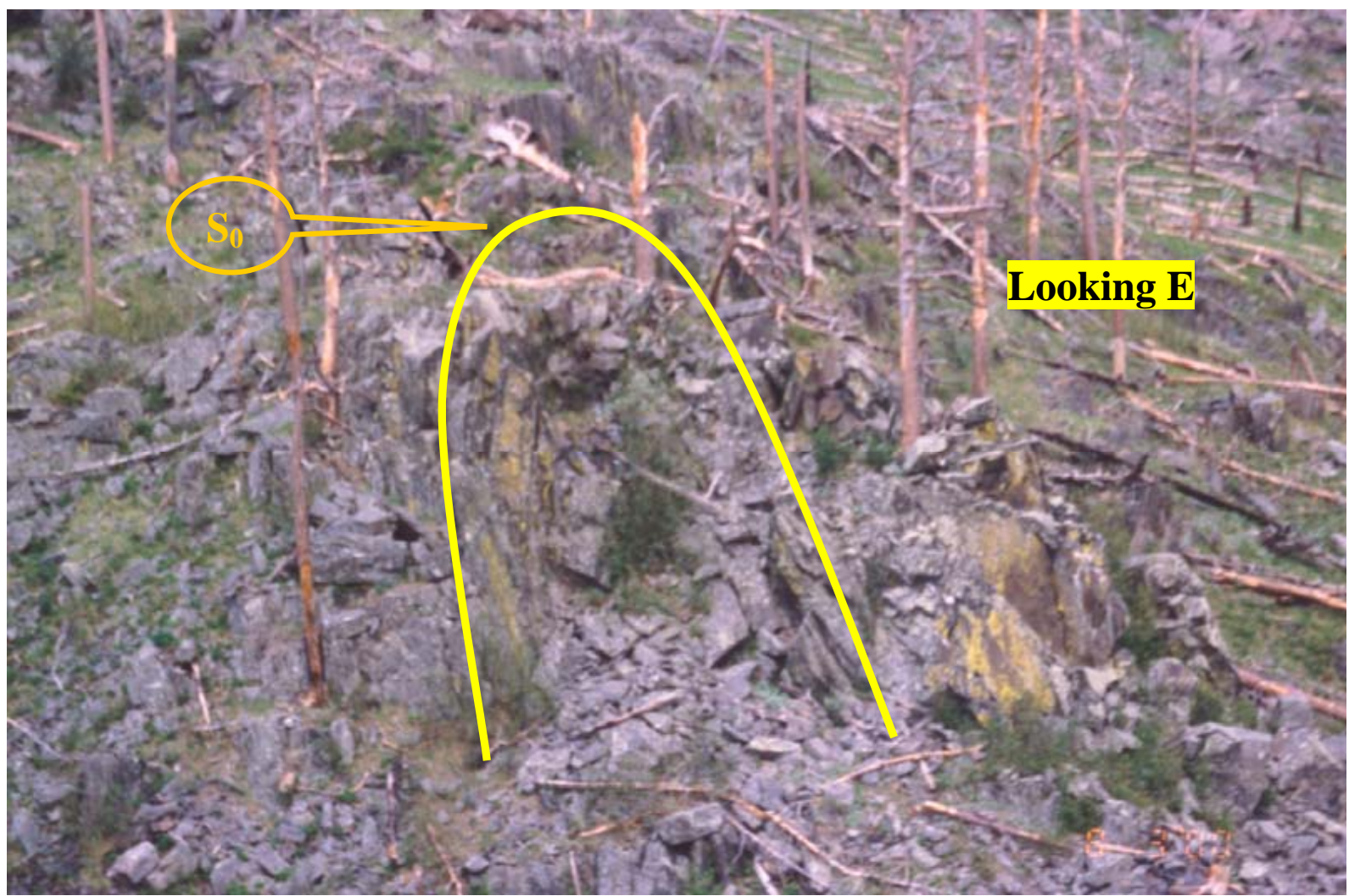

Fig. (12). A nearly non-plunging, tight, isoclinal, and asymmetric anticlinal $\mathrm{F}_{4}$ fold deforms the quartzite beds of $\mathrm{Xgw}_{1}$.

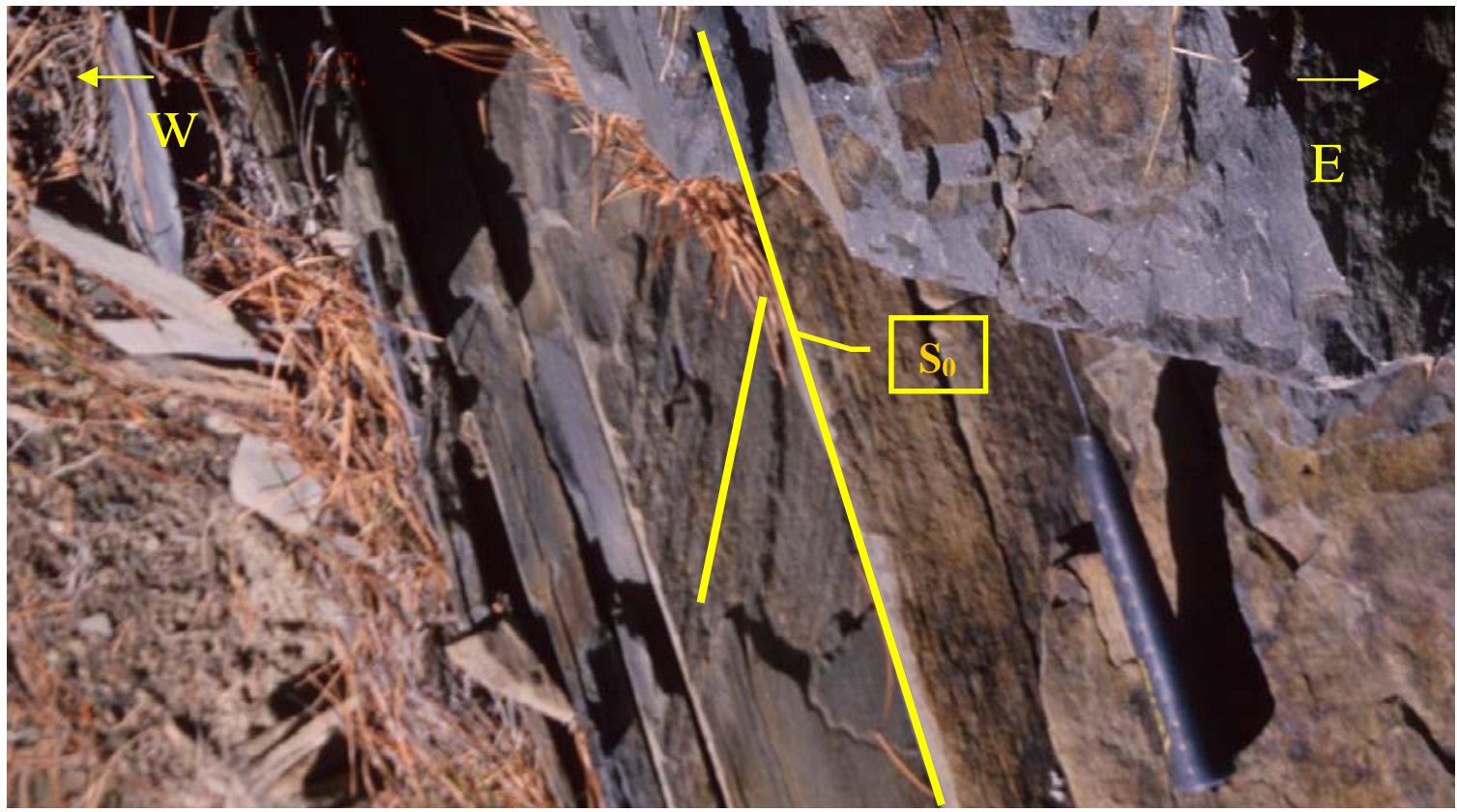

Fig. (13). Incipient cleavage $\left(\mathrm{S}_{4}\right)$ in a bed of the $\mathrm{Xgw}_{2}$ unit is oblique to the bedding.

maxima and sub-maxima of poles to $\mathrm{S}_{0}$ suggest a constant strike $\left(\mathrm{N} 10^{\circ} \mathrm{W}\right)$ with minor development of Z-type minor folds.

\section{Domain IV}

Domain IV lies to the west of Domain I, north of Domain $\mathrm{V}$, and south of Domain III. Only $\mathrm{Xgw}_{1}$ is exposed in this domain. $F_{2}$ folds trend northwesterly and lie west of the
Horse Creek dome (Fig. 15). Poles to bedding $\left(\mathrm{S}_{0}\right)$ produce two major maxima $\left(3^{\circ}, \mathrm{S} 66^{\circ} \mathrm{W}\right.$ and $\left.9^{\circ}, \mathrm{N} 59^{\circ} \mathrm{W}\right)$ that are also monoclinic (Fig. 14d). This distribution suggests nearly isoclinal folding with minor development of Z-type minor folds. Poles to $\mathrm{S}_{2}$ are just few disseminated points to produce any pattern, but they do show a wide range of plunges. This suggests that $\mathrm{S}_{2}$ is folded by a younger deformational event. 


\section{4.a. Domain I.}
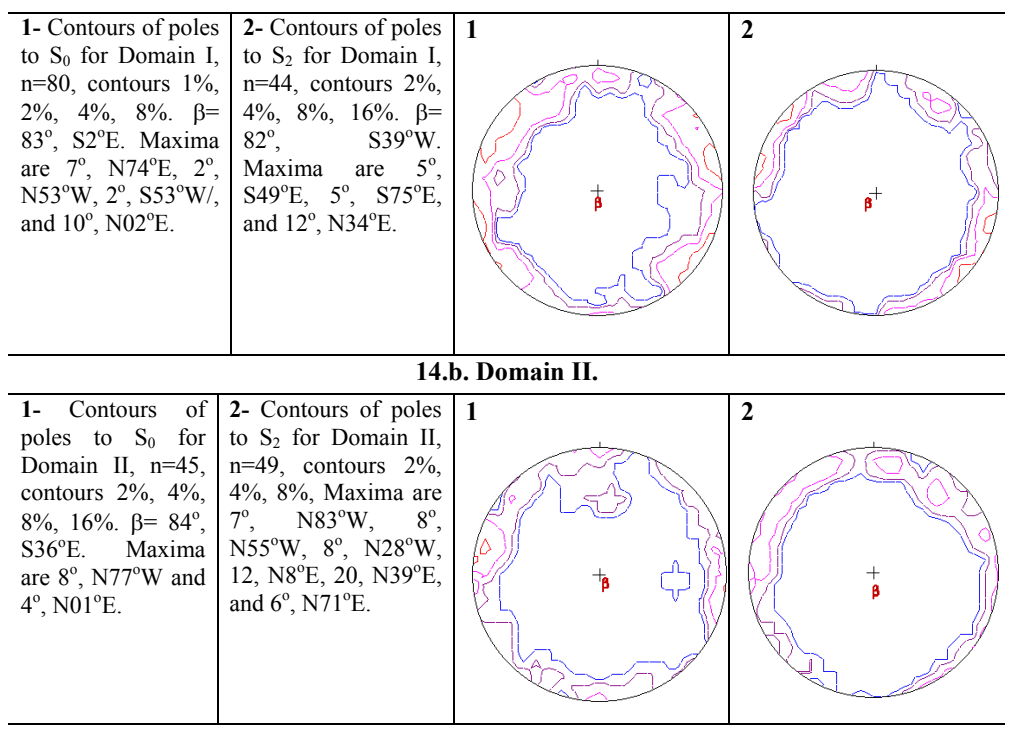

14.c. Domain III.

1- Contours of poles to $\mathrm{S}_{0}$ for Domain III, $\mathrm{n}=16$, contours $6 \%, 12 \% . \beta=71^{\circ}, \mathrm{S} 2^{\circ} \mathrm{W}$. Maxima is $11^{\circ}, \mathrm{N} 88^{\circ} \mathrm{W}$, and sub-maxima is $11^{\circ}, \mathrm{N} 48^{\circ} \mathrm{W}$.

2- $\mathrm{S}_{0}$ in parallelism with $\mathrm{S}_{0}$

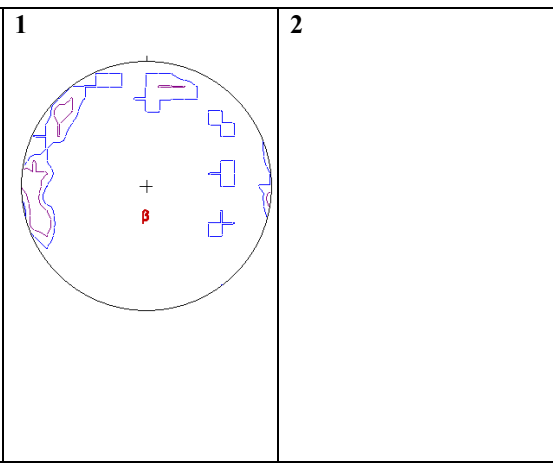

14.d. Domain IV.

1- Contours of poles to $S_{0}$ for Domain IV, $\mathrm{n}=40$, contours $2 \%, 4 \%, 8 \%, 16 \%$. $\beta=82^{\circ}$, $\mathrm{S} 39^{\circ} \mathrm{W}$. Maxima are $3^{\circ}, \mathrm{S} 66^{\circ} \mathrm{W} /$ and $9^{\circ}$, $\mathrm{N} 59^{\circ} \mathrm{W}$.

2- $\mathrm{S}_{2}$ In parallelism with $\mathrm{S}_{0}$

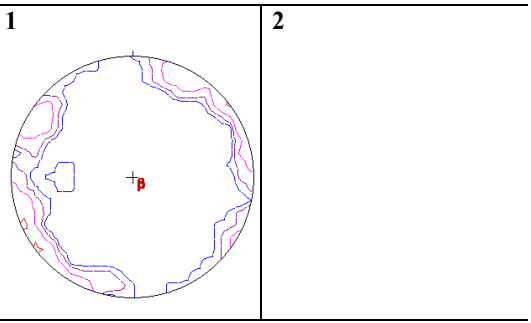

14.e. Domain V

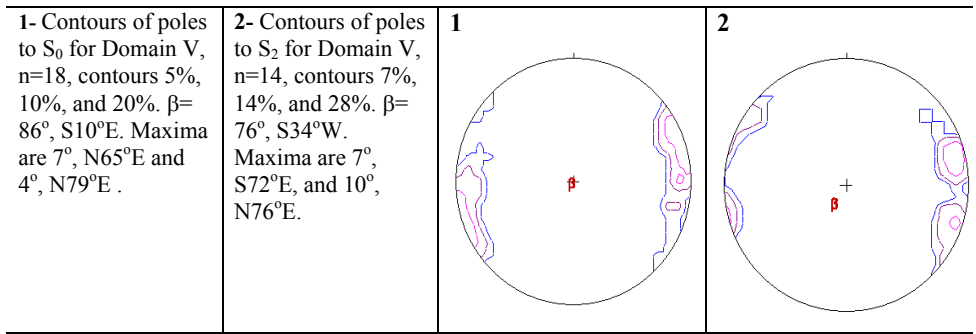

14.f. Explaination of stereographic projection interpretations, mentioned in the text.

1- Major limb with $\quad$ 2- Major limb with 1 Z-type minor fold. $\quad$ S-type minor fold.

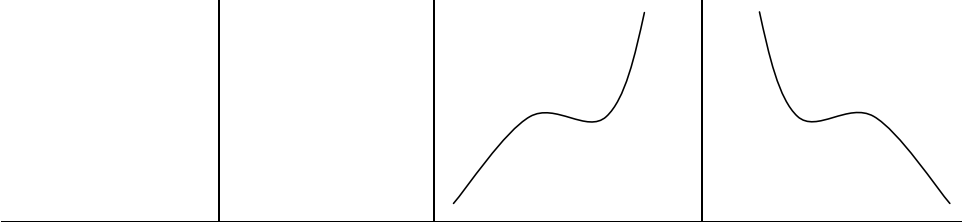

Fig. (14). S0 and S2 equal area stereographic projections, and interepretations. 


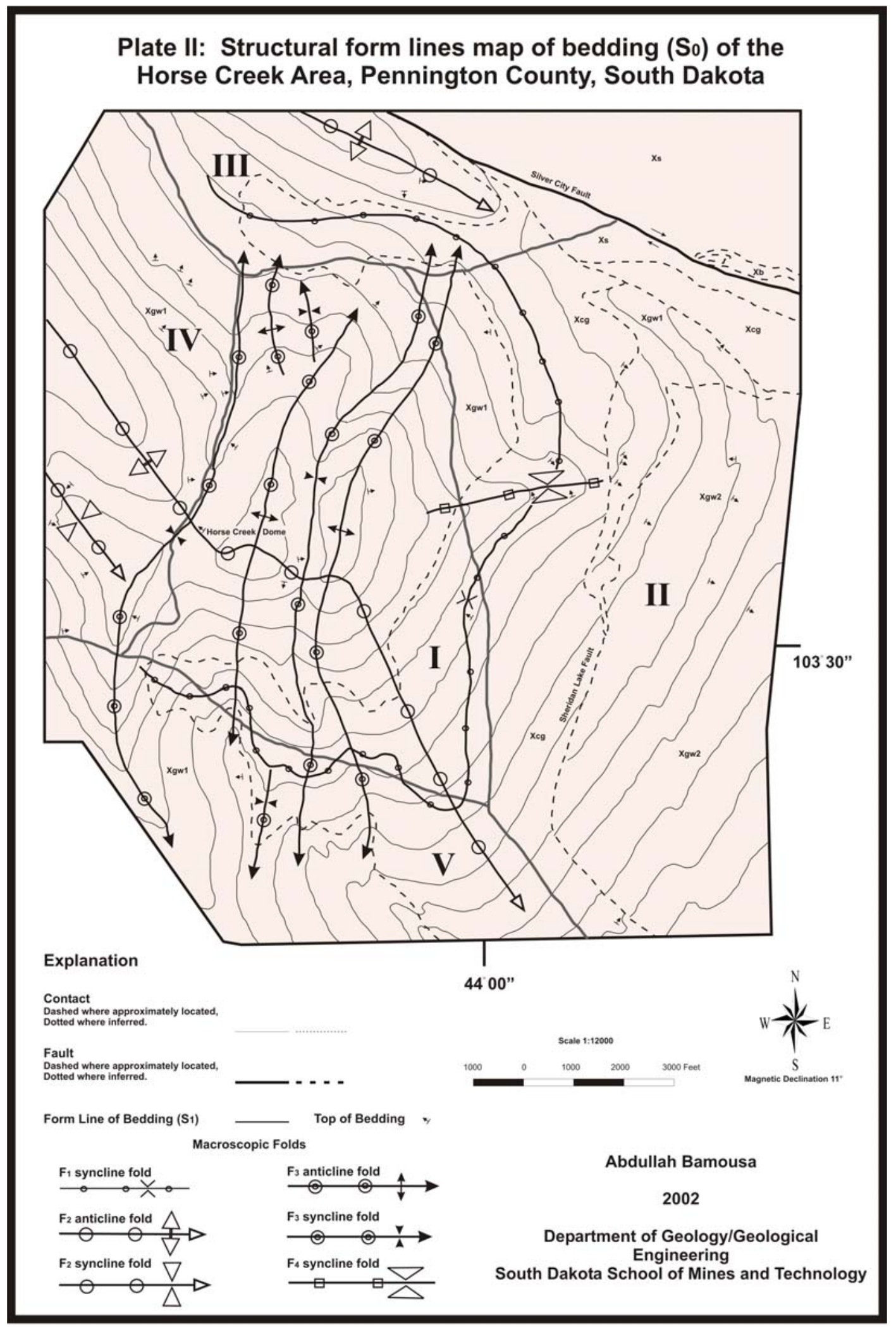

Fig. (15). Detailed structural map of the study area, showing superposed folds, domain analysis and S0 form lines.

\section{Domain V}

This domain occupies the area south of Domain I and west of Domain II. The southern nose of the Xcg unit and the surrounding rocks of $\mathrm{Xgw}_{1}$ are exposed in this domain, in which the Xcg unit in the nose of the $F_{1}$ has been overprinted by $\mathrm{F}_{3}$ (Fig. 15). Poles to bedding $\mathrm{S}_{0}$ produce a lesser maxima at $\left(4^{\circ}, \mathrm{N} 79^{\circ} \mathrm{E}\right)$ and a dominant maxima at $\left(7^{\circ}, \mathrm{N} 65^{\circ} \mathrm{W}\right)$ that also display monoclinic symmetry (Fig. 13e). The elongation 
of the dominant maxima suggests either the presence of Stype minor folds, or slight deviations in strike due to incompetent material Besides, both the lesser maxima and the dominant maxima suggest a constant strike $\left(\mathrm{N} 25^{\circ} \mathrm{W}\right)$ with minor development of Z-type minor folds. Poles to $\mathrm{S}_{2}$ cleavages produce two equally developed concentration $\left(7^{\circ}\right.$, $\mathrm{S} 72^{\circ} \mathrm{E}$, and $10^{\circ}, \mathrm{N} 76^{\circ} \mathrm{E}$ ), which suggest two major limbs of tight, steeply inclined fold without any indication of refraction that suggest minor folds (Fig. 14f).

\section{DISCUSSION AND CONCLUSIONS}

Redden and DeWitt [17] and Redden et al. [4] adapted Bamousa [2] mapping of $\mathrm{F}_{1}$ fold, within the Xcg unit. However, they designated an E-W anticline, in the middle of the Horse Creek dome, within the $\mathrm{Xgw}$ unit, as $\mathrm{F}_{1}$ fold. Moreover, Redden et al. [4] designated the N-S cross-folds in domain II as $F_{2}$ folds. Therefore, their mapping of the (1:24000) Silver City Quadrangle suggests that the Horse Creek dome developed by superposition of $F_{2}$ and $F_{1}$ folds. This, in the opinion of the author, is not feasible because this study shows clearly refolded $\mathrm{F}_{2}$ folds, and folded $\mathrm{S}_{2}$ cleavages. Also, in type-2 interference, the crescent shape is cross-folded in the middle by the youngest folding event (Fig. 15). Therefore, the folds that trend $\mathrm{E}-\mathrm{W}$ inside the crescent shape, have to be $F_{2}$ antiform fold. Thus, the N-S cross-folds should be $\mathrm{F}_{3}$ folds.

As a result, the crescent fold was formed by the Xcg unit that forms a syncline $\left(F_{1}\right)$ and is cross-folded by $F_{2}$ folds. It is best explained by Ramsay's [18] Type-2 interference folding, which is feasible by superposition of the first two slip movements $[19,20]$. The geological pattern of the metaconglomerate or the crescent shape tends to follow domal structure that was developed by superposition of northnortheasterly trending $F_{3}$ folds on westerly trending $F_{2}$ folds. Type- 2 interference is less complicated than that found in the study area, according to tops of F1 that suggest isolcinal syncline fold (Fig. 15), and the area is deformed by more than two generations of folds. Maxima of poles to $S_{0}$ and $S_{2}$ of each domain show asymmetric maxima on equal area stereonet projections, which define monoclinic symmetries. A monoclinic symmetry occurs when two oblique generations of deformation are superposed [21].

\section{ACKNOWLEDGEMENT}

The author would like to thank anonymous reviewers for their comments, and Alvis Lisenbee and Jack Redden for their supervision at South Dakota School of Mines and Tech. This project was part of a scholarship provided by King Abdul-Aziz University, Madinah Branch.

\section{CONFLICT OF INTEREST}

Declared none.

\section{REFERENCES}

[1] Redden JA, Peterman ZE, Zartman RE, DeWitt E. U-Th-Pb geochronology and preliminary interpretation of Precambrian tectonic events in the Black Hills, South Dakota. In: Lewry JF, Stauffer MR, Eds. The Early Proterozoic Trans-Hudson Orogen of North America: Geological Association of Canada Special Paper. 1990; 37: 229 - 51.

[2] Bamousa AO. Structural analysis of the Precambrian rocks in the Horse Creek Area, Pennington County, South Dakota. MS thesis. Rapid City, South Dakota: South Dakota School of Mines and Technology 2002.

[3] Norton JJ, Redden JA, Anderson FJ. Geologic Map of the Pactola Dam Quadrangle. South Dakota: South Dakota Geological Survey Map 8, 2008.

[4] Redden JA, Alexander D, Nonnast D. Geologic Map of the Silver City Quadrangle. South Dakota Geological Survey Map 12, 2010.

[5] Ratté JC, Wayland RG. Geology of the Hill City quadrangle, Pennington County, South Dakota - a preliminary report. U.S. Geological Survey, Bulletin 1271-B, 1969; p. 14.

[6] Redden JA, French GM. Geological setting and potential exploration guides for gold deposits, Black Hills, South Dakota. U.S. Geological Survey, Bulletin 1857-B, 1989;B45.

[7] Duke EF. Geochmistery of Lower Proterozoic metagreywacke, Black Hills, South Dakota: regional and outcrop-scale variation. In: Paterson CJ, Kirchner JG, Eds. Guidebook to the geology of the Back Hills. South Dakota School Mines Technol Bull 1996; 19: 180-90.

[8] Dahl PS, Holm DK, Hubacher FA, Foland KA. New constraints on the timing of Early Proterozoic tectonism in the Black Hills (South Dakota) with implications for docking of the Wyoming province with Laurenita. Geol Soc Am Bull 1999; 111: 1335-49.

[9] Nabelek PI, Liu M. Leucogranites in the Black Hills of South Dakota: The consequence of shear heating during continental collision. Geology 1999; $27: 523-6$.

[10] Chappell BW, White ARJ. Two contrasting granite types: 25 years later. Aust J Earth Sci 2001; 48: 489 - 99.

[11] Helms, TS, Labotka TC. Petrogenesis of Early Proterozoic pelitic schists of the southern Black Hills, South Dakota: Constraints on regional low pressure metamorphism: Geol Soc Am Bull 1991; 103: p. 1324 - 34.

[12] Paterson, CJ, Lisenbee AL, Eds. Metallogeny of gold in the Black Hills, South Dakota. Fort Collins, Colorado: Society of Economic Geologists 1992; 7: p 190.

[13] Friberg LM, Dahl PS, Terry MP. Thermotectonic evolution of Early Proterozoic metamorphic rocks from Southern Black Hills, South Dakota. In Paterson CJ, Kirchner JG, Eds. Guidebook to the geology of the Back Hills. South Dakota School Mines Technol Bull 1996; 19: 191-9.

[14] Paterson CJ, Kirchner JG,Eds. Guidebook to the geology of the Black Hills, South Dakota. South Dakota School Mines Technol Bull 1996; 19: p 230.

[15] DeWitt, E., J.A. Redden, A.B. Wilson, and D. Buscher, 1989, Geologic map of the Black Hills Area, South Dakota and Wyoming: U.S. Geological Survey Map I-1910.

[16] Wavra CS. Structural and petrofabric analysis of some Precambrian tectonites within the Berne 7.5 minute quadrangle, Black Hills South Dakota. Ph.D. Dissertation. Moscow: University of Idaho 1989.

[17] Redden JA, DeWitt E. Maps Showing Geology, Structure, and Geophysics of the Central Black Hills, South Dakota, USGS 2008.

[18] Ramsay JG. Folding and fracturing of rocks. New York: McGraw-Hill 1967.

[19] Whitten TEH. Structural geology of folded rocks. Chicago: Rand McNally and Co 1966.

[20] Twiss RJ, Moores EM. Structural geology. New York: Freeman and Co 1992.

[21] Turner, FJ, Weiss LE. Structural analysis of metamorphic tectonites. New York: McGraw-Hill 1963. 